\title{
Long-term drought sensitivity of trees in second-growth forests in a humid region
}

\author{
Neil Pederson, Kacie Tackett, Ryan W. McEwan, Stacy Clark, Adrienne Cooper, \\ Glade Brosi, Ray Eaton, and R. Drew Stockwell
}

\begin{abstract}
Classical field methods of reconstructing drought using tree rings in humid, temperate regions typically target old trees from drought-prone sites. This approach limits investigators to a handful of species and excludes large amounts of data that might be useful, especially for coverage gaps in large-scale networks. By sampling in more "typical" forests, network density and species diversity would increase in ways that could potentially improve reconstructions. Ten nonclassical tree-ring chronologies derived from randomly selected trees, trees from logged forests, or both were compared to more classical chronologies and an independent regional drought reconstruction to determine their usefulness for dendrohydroclimatic research. We find that nonclassical chronologies are significantly correlated to classical chronologies and reconstructed drought over the last 2-3 centuries. While nonclassical chronologies have spectral properties similar to those from classical dendroclimatic collections, they do lack spectral power at lower frequencies that are present in the drought reconstruction. Importantly, our results show that tree growth is strongly dependent on moisture availability, even for small, randomly selected trees in cut forests. These results indicate that there could be more data available in areas with few current tree-ring collections for studying climate history and that drought plays an important role in humid forests.
\end{abstract}

Résumé : Les méthodes de terrain classiques pour reconstituer les périodes de sécheresse à l'aide des cernes des arbres dans les régions tempérées humides ciblent typiquement les vieux arbres dans les stations sujettes à la sécheresse. Cette approche limite les chercheurs à une poignée d'espèces et exclut de grandes quantités de données qui pourraient être utiles, particulièrement pour les bris de couverture dans les réseaux à grande échelle. En échantillonnant dans des forêts plus typiques, la densité des réseaux et la diversité des espèces augmenteraient, ce qui pourrait améliorer les reconstitutions. Dix séries dendrochronologiques non classiques dérivées d'arbres choisis au hasard, d'arbres provenant de forêts coupées, ou des deux, ont été comparées à des séries dendrochronologiques plus classiques et à une reconstitution indépendante des périodes de sécheresse régionale pour déterminer leur utilité pour la recherche en dendrohydroclimatologie. Nous avons trouvé que les séries dendrochronologiques non classiques sont significativement corrélées avec les séries dendrochronologiques classiques et avec les périodes de sécheresse reconstituées au cours des derniers deux à trois siècles. Alors que les séries dendrochronologiques non classiques ont des propriétés spectrales semblables à celles des collections dendroclimatiques classiques, elles n'ont pas la puissance spectrale aux fréquences plus faibles qui est présente dans la reconstitution des périodes de sécheresse. Nos résultats montrent surtout que la croissance des arbres est fortement dépendante de l'humidité disponible, même celle des petits arbres choisis au hasard dans les forêts coupées. Ces résultats indiquent que plus de données pourraient être disponibles dans les régions qui comptent actuellement peu de collections dendrochronologiques pour l'étude du climat passé et que la sécheresse joue un rôle important dans les forêts humides.

[Traduit par la Rédaction]

\section{Introduction}

Many classical, tree-ring based drought reconstructions target trees from old-growth forests or forests that are largely undisturbed by human land use. However, the amount of old-growth forest in humid regions is low. As one example, the amount of old-growth forest (defined here as forests with no logging history) in the eastern United States represents approximately $0.5 \%$ of the forested landscape (Davis 1996). Regions with productive soils, low topographical relief, and a relatively high amount of rainfall have even less old-growth forest. For the North American Drought Atlas (NADA) (Cook et al. 2010), this results in gaps of the underlying tree-ring network. Although the awareness

Received 11 March 2012. Accepted 23 August 2012. Published at www.nrcresearchpress.com/cjfr on xx September 2012.

N. Pederson*, K. Tackett, A. Cooper, G. Brosi, R. Eaton, and R.D. Stockwell. Cumberland Laboratory of Forest Science,

Department of Biological Sciences, Eastern Kentucky University, 521 Lancaster Avenue, Richmond, KY 40475, USA.

R.W. McEwan. Department of Biology, University of Dayton, 300 College Park, Dayton, OH 45469-2320, USA.

S. Clark. USDA Forest Service, Southern Research Station, 2431 Joe Johnson Drive, Rm. 274, Knoxville, TN 37996-4563, USA.

Corresponding author: Neil Pederson (e-mail: adk@ldeo.columbia.edu).

*Present address: Tree Ring Laboratory of Lamont-Doherty Earth Observatory and Columbia University, 61 Rt. 9w, Palisades, NY 10964, USA. 
and discovery of old-growth forest increased during the 1990s (Davis 1996), there is little guarantee that old-growth forests will remain intact, i.e., retain the natural integrity of structure and function in old, uncut forests. In addition to the threat of future pests and diseases, old-growth forest is still being lost due to logging. Therefore, when following the classical approach of relying upon old-growth forests, the amount of land that can be used for climatic reconstructions is extremely limited.

Another classical approach for reconstructing drought in humid to perhumid environments is to target trees growing on dry sites with low water-holding capacity or high evaporative demand. This has many benefits. First, dry sites have lower productivity and are less likely to have been extensively logged. In fact, low productivity sites are some of the better places to search for old-growth forests in humid regions (Stahle and Chaney 1994). Second, because drier sites tend to be lower in productivity, they tend to have lower tree density and less tree-to-tree competition. Because of this, ring width patterns of trees from more xeric sites in humid region are more likely to be driven by climatic variation than by disturbance. Third, trees on dry sites tend to be mostly drought sensitive (e.g., Cook and Jacoby 1977; Stahle and Cleaveland 1988), although there exceptions such as baldcypress (Taxodium distichum (L.) Rich.) growing in wetlands (Stahle and Cleaveland 1992). Finally, recent evidence suggests that trees growing on adverse sites or experiencing suppression or negative climatic conditions tend to have greater longevity (e.g., Black et al. 2008; Di Filippo et al. 2012). Thus, the targeting of trees on drought-prone sites in humid environments often results in older trees with stronger drought signals than disturbance signals embedded in their rings.

There is an important limitation, however, to targeting drier sites in humid environments. Sampling only dry sites can limit investigators to a handful of species. In eastern North America, this roughly translates to $<10 \%$ of the $300+$ canopy tree species. This is an important limitation because recent work indicates that a multispecies network improves climate reconstructions (García-Suárez et al. 2009; Cook and Pederson 2011; Maxwell et al. 2011; Pederson et al. 2012b). And, considering the increased rate of species extinction, new sources of dendroclimatic material are needed. Hemlock (eastern hemlock (Tsuga canadensis (L.) Carrière) and Carolina hemlock (Tsuga caroliniana Engelm.)), a commonly used dendroclimatic species (Hessl and Pederson 2013), is becoming functionally extinct over much of its range. The discovery of new dendroclimatically sensitive species is important for future studies.

Fortunately, the number of scientists using tree rings to study past environments over the past two decades has increased. Many of these scientists are collecting samples for reasons other than reconstructing climate history and, sometimes, in forests with a significant amount of human disturbance (e.g., Druckenbrod and Shugart 2004; Davis et al. 2009; Hart et al. 2012). If some of these data are useful for paleoclimatic investigations, there can be an increase in the spatial density and species diversity of chronologies for paleoclimatic research.
Here, we explore a new approach to dendropaleoclimatic research in two ways. First, we examine the long-term radial growth patterns of trees from second-growth forests. Second, Cook (1982) suggested that site selection for dendrohydroclimatic research does not matter as one might suppose in the temperate forests of humid, eastern North America - tree age is more important. Here, we test the conjecture by using tree-ring collections from forests with different land-use histories and site types. The exploration of data from different forest types gives us the opportunity to investigate the usefulness of new species as possible replacements for hemlock. Finally, some of the new collections used here also allow us to compare radial growth of "typical" trees (trees from randomly placed plots in logged forests) versus targeted trees. This analysis will give insight to the long-term climatic sensitivity of much of today's forests.

Eastern Kentucky is a good region to conduct this investigation, as (1) there are currently only two chronologies in NADA for eastern Kentucky and (2) the long and heavy land-use history in this region has created at least one anthropogenic ecosystem (McEwan and McCarthy 2008); forests thought to be old-growth turn out to have much anthropogenic disturbance (Cooper 2011). Additionally, the considerable topographical variation in eastern Kentucky could play a role in tree growth across our network. If coherency between these records is found at short and long time scales, it suggests that climate influences radial growth across contrasting land uses and site types. Therefore, our investigation will provide insight into the usefulness of tree-ring records from nonclassical sites for regions with little old-growth forest.

\section{Methodology}

\section{Study region and sites}

Our 10 new chronologies are distributed over three physiographic provinces and span approximately $4200 \mathrm{~km}^{2}$. Collections were made in 10 areas (Fig. 1; Table 1; Supplemental Material: Additional Site History Information, Fig. S1). ${ }^{1}$ Five of these areas are in the London Ranger District of the Daniel Boone National Forest, while the remaining collections are from forest preserves. In this region, average total annual precipitation is $1194.3 \mathrm{~mm}$, while average temperature is $1.6{ }^{\circ} \mathrm{C}$ in January and $24.0^{\circ} \mathrm{C}$ in July (NOAA's National Climatic Data Center: http://www.ncdc.noaa.gov/temp-andprecip/time-series/).

The London Forest tulip-poplar (Liriodendron tulipifera L.) was derived from the 2706 ha Cane Creek Wildlife Management Area in the Daniel Boone National Forest, a multiaged, mature second-growth ravine forest comprised of hemlock and mixed-mesophytic species (Tackett 2012), and the nearby Angel Hollow forest, an old forest with evidence of anthropogenic disturbance (Cooper 2011; Supplemental Material Fig. S1c). The proximity of the two sites and high correlation between both sites $(r=0.607$ for the common period with at least four cores, 1780-2007, $p<0.0001$ ) allowed for the combination of the L. tulipifera collections. Collections of white oak (Quercus alba L.), chestnut oak (Quercus montana Willd.), and T. canadensis were made in the old-growth forest at Blanton Forest, a 1264 ha preserve where approximately

${ }^{1}$ Supplementary data are available with the article through the journal Web site at http://nrcresearchpress.com/doi/suppl/10.1139/x2012-130. 
Fig. 1. Map of the eastern Kentucky tree-ring network used here. Three chronologies were collected in Blanton Forest, while two were collected from Griffith Woods. Chronologies were created from cores at Rock Creek and Cane Creek (see Fig. 2d) and Rock Creek and Angel Hollow (see Fig. 2i). Lilley Cornett Woods and Mammoth Cave, chronologies collected in the 1980s, are a part of the North American Drought Atlas.

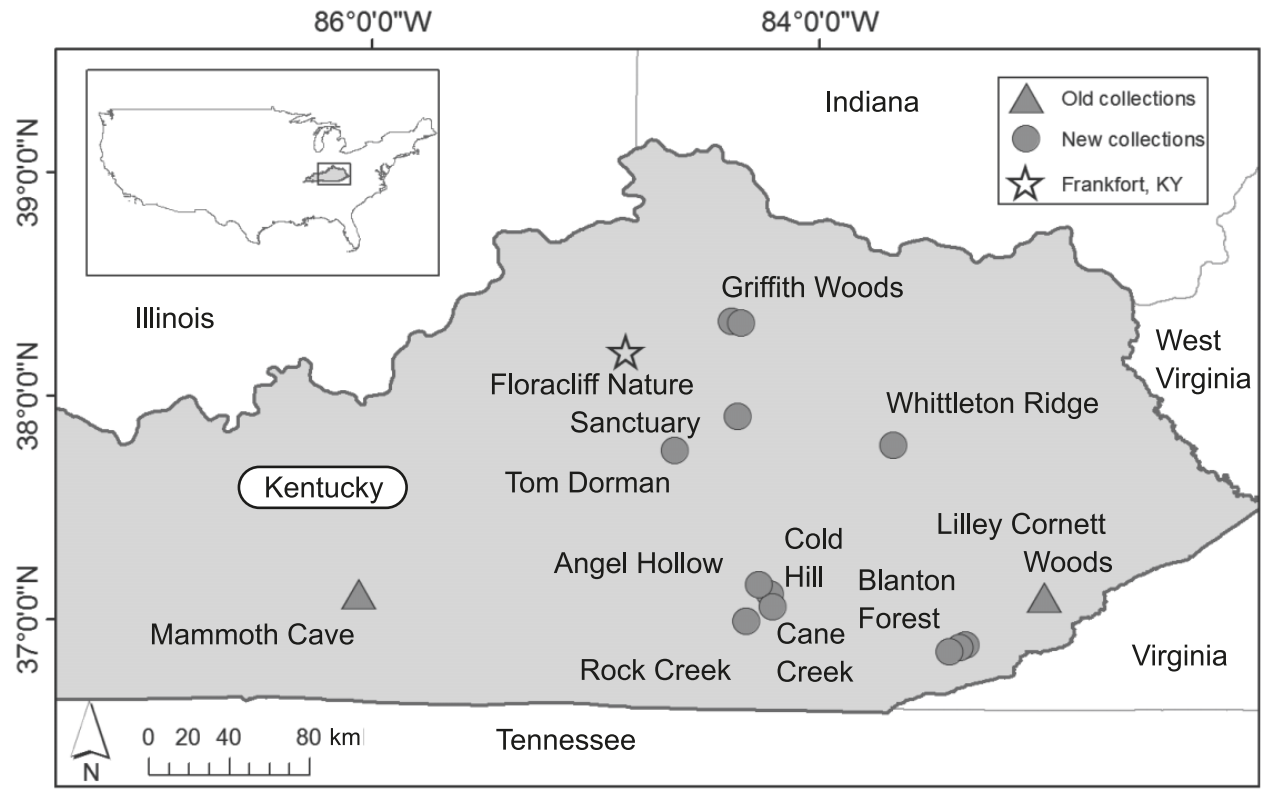

Table 1. Chronology statistics for new chronologies from the eastern Kentucky network.

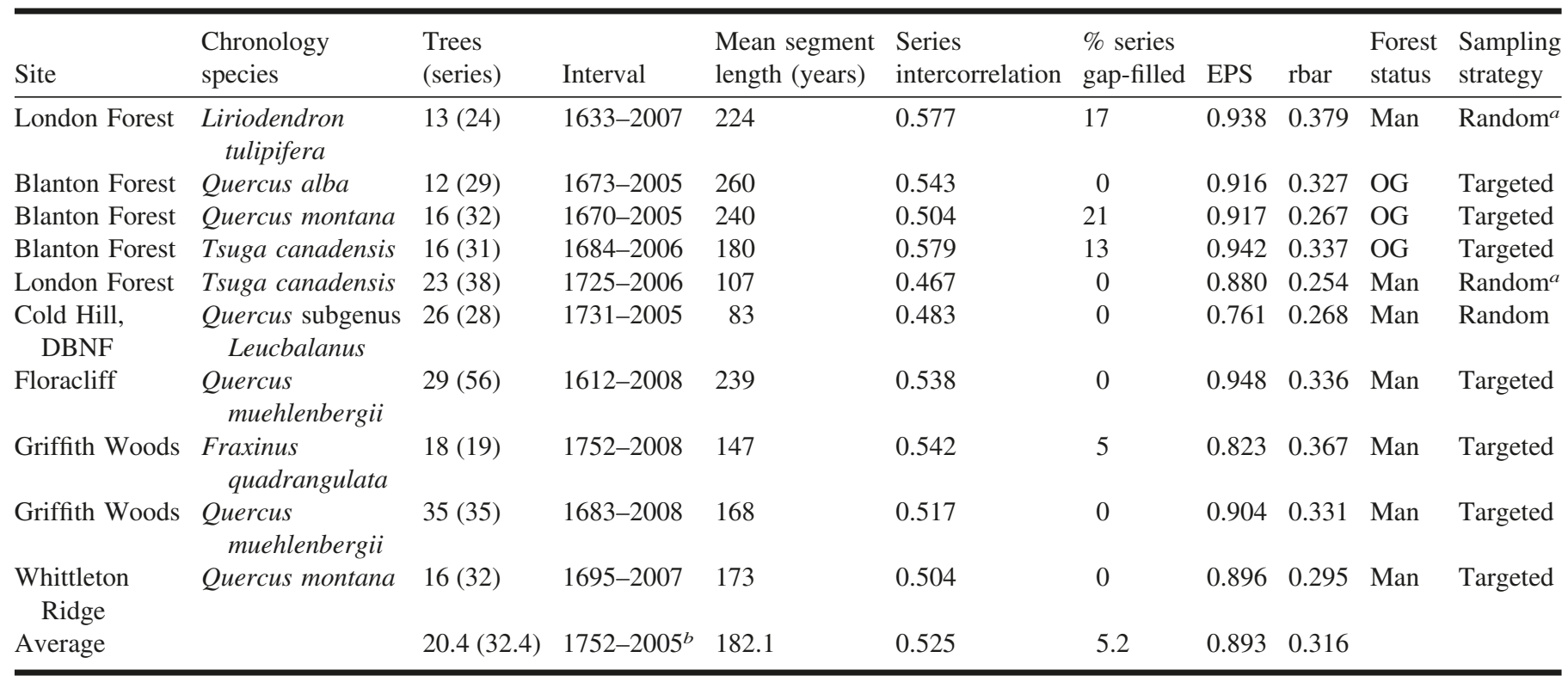

Note: DBNF, Daniel Boone National Forest. See the Methodology section for descriptions for EPS and rbar. \% series gap-filled, percentage of series in each collection with gaps that were filled via the program ARSTAN. Man, managed forest; OG, old-growth forest; random, trees from randomly selected plots; targeted, trees collected through targeted sampling. See text for more details.

${ }^{a} \mathrm{~A}$ few trees in this collection were targeted for age. See text for more details.

${ }^{b}$ Common interval.

$67 \%$ is old-growth forest. The London Forest T. canadensis was composed of trees from Cane Creek and Wildlife Management Area and Rock Creek Research Natural Area, a 430 ha mixed-mesophytic forest with a mix of old-growth forest and patches of selective cutting (Tackett 2012; Supplemental Material Fig. S1b). Proximity and high correlation $(r=$ 0.609 from 1780 to $2006, p<0.0001$ ) allowed for the com- bination of these collections. The Cold Hill Quercus subgenus Leucobalanus chronology is composed of $Q$. alba and $Q$. montana. Cold Hill, on the plateau above Cane Creek, is a second-growth forest that has been logged and burned from the late 19th century to approximately the 1970s. Because replication back in time was low for both species on Cold Hill, both have a similar climatic response (Pederson et al. 2004), 
and they correlate well $(r=0.653$ from 1910 to 2005, $p<$ 0.0001 ), samples were combined into one chronology. The Floracliff chinkapin oak (Quercus muehlenbergii Engelm.) is a combination of cores from Floracliff Nature Sanctuary, a 116 ha second-growth forest with abandoned agricultural land and scattered old, remnant trees, and Tom Dorman State Nature preserve, a 300 ha preserve with a similar forest structure and land-use history as Floracliff. Being geographically and ecologically similar and having high correlation between trees from both forests ( $r=0.640$ from 1710 to 2007, $p<0.0001)$ allowed for improved replication through the combination of both collections. Chronologies of blue ash (Fraxinus quadrangulata Michx.) and Q. muehlenbergii were made at Griffith Woods, a 301 ha preserve with open-grown trees in a savanna-woodland ecosystem (Supplemental Material Fig. S1a). While initially hypothesized to be a preEuropean settlement ecosystem, Griffith Woods is likely anthropogenic in origin (McEwan and McCarthy 2008). Finally, the Whittleton Ridge Q. montana chronology was collected from a forest that was heavily cut during the 20th century (Supplemental Material Fig. S1d). Two additional chronologies were downloaded from the International Tree-Ring Databank (ITRDB). Collections of $Q$. alba were made in Mammoth Cave National Park in 1966 by E.T. Estes and in 1986 by E.R. Cook, while a collection of $Q$. alba was made from Lilley Cornett Woods in 1983 by E.R. Cook and others. Both collections targeted trees from old-growth forest. Species nomenclature follows Jones (2005).

\section{Field methods}

Standard dendroclimatological techniques were used when possible. While the oldest-looking individuals were targeted (Stahle and Chaney 1994; Pederson 2010), collections made in second-growth forest make the final chronologies a hybrid of classical and nonclassical approaches. For example, the number of old $F$. quadrangulata at Griffith Woods forest was limited. Therefore, chronology length and replication were boosted by samples from remnant forests within $20 \mathrm{~km}$ of Griffith Woods (see McEwan and McCarthy 2008).

Even less classical dendroclimatic sampling was employed at Angel Hollow, Cane Creek, Cold Hill, and Rock Creek. At Angel Hollow, trees $>10 \mathrm{~cm}$ diameter at breast height (DBH) were selected using the point-center quarter transect method along $100 \mathrm{~m}$ transects (Cooper 2011). At Cane Creek and Rock Creek, plots were randomly located prior to field sampling and all in-plot trees $\geq 10 \mathrm{~cm}$ DBH were cored (Tackett 2012). Similarly, all $Q$. alba and Q. montana in the Cold Hill District $\geq 10 \mathrm{~cm}$ DBH were cored in plots placed systematically within six random locations (Schweitzer et al. 2008). The youngest $Q$. alba and $Q$. montana cored at Cold Hill, $<50$ years, were not used, as they would not typically be used for dendroclimatic research. To boost sample depth of older trees at Angel Hollow, Cane Creek, and Rock Creek, a few old-looking T. canadensis and L. tulipifera were cored outside the designated plots or transects (Cooper 2011; Tackett 2012). Most trees cored in these forests were collected through random selection sampling.

Project goals and collection restrictions resulted in other deviations from classical dendroclimatological methods. Sampling protocol dictated the collection of one core per tree from the Cold Hill Q. alba and Q. montana and the Griffith Woods F. quad- rangulata and $Q$. muehlenbergii. Three cores per T. canadensis and L. tulipifera tree were removed at Cane Creek and Rock Creek, although only two cores per tree were used here.

\section{Laboratory methods}

All core samples were prepared using standard techniques (Cook and Kairiukstis 1990). Each core was visually crossdated using marker rings and then measured to the nearest $0.001 \mathrm{~mm}$. Visual crossdating was verified using the program COFECHA (Holmes 1983).

Raw ring width measurements for each collection were processed into separate tree-ring chronologies using the program ARSTAN (Cook 1985; Cook and Krusic 2011). A small number of cores required "gap-filling" because of sections with distorted ring widths, areas of rot, or missing sections of wood; an average of $5.2 \%$ of all series were gap-filled, although series from six collections required no gap-filling (Table 1). Gaps were modeled and filled to reduce the "segment length curse" (Cook et al. 1995; Pederson et al. 2004). Variance of all series was stabilized using the adaptive power transformation, rbar-weighted, or spline stabilization procedures (Cook and Kairiukstis 1990). Tree-ring widths were detrended to retain as much low-frequency information as possible while removing step-changes in ring width that likely arise from canopy disturbance (Cook and Peters 1981; Pederson et al. 2004). The first step of this process uses negative exponential or negative linear curves to remove trends that likely are related to decline in ring widths as the stem expands. For series lacking a negative trend in ring widths, ARSTAN automatically fit a horizontal line through the mean of the series. The second step was to go through all series following the first detrending to remove abrupt changes in ring width related to canopy disturbance using the Friedman Super Smoother (Friedman 1984). For series with no obvious change in ring width resembling a growth release, a horizontal straight line was fit through the mean. The detrended time series were combined into an annual mean for each population using a biweight robust mean function (Cook 1985). rbar, the mean correlation of all time series in a sample collection, and the expressed population signal (EPS) were used to quantify chronology quality (Cook and Kairiukstis 1990); a chronology with an EPS of 0.85 is generally considered sufficient for climatic reconstructions. The ARSTAN chronology of each collection is used in these analyses, as this chronology type is partially composed of common lower-frequency variation within a collection that is suspected to derive from outside the sampled forest and more likely to be regional climate (Cook 1985).

Principal component analysis (PCA) and varimax rotated principal component analysis (RPCA) were used to identify common patterns of growth between chronologies and to combine time series from different collections. Eigenvector rotation helps preserve factor-loading orthogonality so that each variable typically loads onto one eigenvector, which results in an increase in interpretation of retained eigenvectors (Richman 1986). The Monte Carlo "Rule-N" technique was used to determine the number of eigenvectors to retain (Preisendorfer et al. 1981). Time series of PCA scores were used to examine patterns of common variance through time.

We used multitaper spectral analysis following Mann and Lees (1996) to investigate the range of periodicities retained in 
all time series. Spectral analysis identifies significant periodicities (or cycles) in a time series and can estimate the strength of the signal (or power) that resides in each periodicity. One goal in dendroclimatic research is to preserve and reconstruct changes in ring widths at low frequencies (periodicities $>10$ years, for example), so that long-term changes in climate can be identified. The multitaper spectral analysis method allows us to compare the power spectra of time series among series created from different field methods or forest conditions to determine their value for dendroclimatic research. Chronologies lacking power in low frequency or having spectral properties dissimilar from reconstructed drought or classical dendroclimatic chronologies could be seen as not useful for dendroclimatic research.

The final test to determine the potential usefulness of nonclassical tree-ring collections for dendroclimatic research was to compare the new collections with (1) each other, (2) the classical collections at Lilley Cornett and Mammoth Cave records, and (3) reconstructed drought from the NADA covering our study region in eastern Kentucky (Cook et al. 2010) using correlation analysis and comparison of spectral properties for each record.

\section{Results}

\section{General network characteristics}

The new chronologies have a common interval from 1752 to 2005 (Table 1; Fig. 2). The longest chronology, Floracliff Nature Sanctuary Q. muehlenbergii, spans 1612-2007. The London Forest L. tulipifera, Floracliff $Q$. muehlenbergii, and Blanton Forest $T$. canadensis collections have the strongest chronology statistics, while the Cold Hill Quercus subgenus Leucobalanus and London Forest $T$. canadensis chronologies are weaker (Table 1). EPS for Cold Hill is above 0.85 for most of the 1900s, drops to 0.60 in the 1890s, and stays below 0.70 into the 1700s. Excepting the low EPS of Cold Hill Quercus subgenus Leucobalanus and Griffith Woods $F$. quadrangulata chronologies, chronology statistics are generally acceptable for tree-ring analysis (Cook and Kairiukstis 1990).

Despite relatively low replication in some chronologies during the 1800s (Fig. 2), series intercorrelation, correlation, and PCA indicate good coherency among most records (Tables 1, 2, and 3). Series intercorrelation for the 1752-2005 common period is $0.525(p<0.0001)$ (Table 1$)$. One of the more striking differences is the sudden and extended drop in ring index during the 1790s of the Inner Bluegrass Province chronologies (Floracliff Nature Sanctuary and Griffith Woods). The remaining records generally show strong and extended above-average ring index during this time (Fig. 2). Because of this and some low replication before 1790, further analyses are limited to 1796-2005 where appropriate.

All chronologies load positively onto the first PCA principal component and RPCA eigenvector (Table 2). The first unrotated principal component accounts for $40.9 \%$ of the common variance among all 12 chronologies. Factor loadings on the first RPCA varimax factor (VF1), accounting for $38.8 \%$ of the common variance, are most heavily weighted by Quercus and the southern chronologies in our network. The second varimax factor (VF2) accounts for $14 \%$ of the variation and is composed primarily of the two T. canadensis chronologies. Chronologies from the northern end of the new network load most strongly on the third varimax factor (VF3) (10.2\% of the annual variance). Conspicuously, Whittleton Ridge, the northernmost collection not in the Inner Bluegrass Province, loaded almost evenly between VF1 and VF3 (Fig. 1; Table 2).

\section{Genera and radial increment patterns within the new network}

Correlation and PCA suggest that genetics matters more than geographic proximity for ring width variation (Tables 2 and 3). Four pieces of evidence indicate that the two $T$. canadensis chronologies are the most dissimilar from the network. First, these series have the lowest correlations compared with the remaining chronologies in the network (Table 3). Second, removing the T. canadensis chronology improves the network series intercorrelation to 0.604. Third, the second component of PCA and RPCA is primarily composed of the $T$. canadensis series. Fourth, the $Q$. alba and $Q$. montana chronologies are more highly correlated with collections of the same species from more than $90 \mathrm{~km}$ away than the $T$. canadensis chronologies from the same forest. In addition, genetic differences appear to be important among the angiosperms. The Griffith Woods $Q$. muehlenbergii chronology was more strongly correlated with the Floracliff Nature Sanctuary $Q$. muehlenbergii chronology than the Griffith Woods $F$. quadrangulata chronology $(r=0.545$ versus $r=0.460$, respectively).

Differences in genetics and radial increment can be seen in the loadings on the first unrotated principal component (Table 2). While all species load positively onto this component, the $T$. $c a-$ nadensis collections are the lowest loadings followed by the singleton $F$. quadrangulata and L. tulipifera chronologies. All Quercus chronologies, save the Cold Hill Quercus subgenus Leucobalanus chronology (low replication and randomly selected trees from a cut forest), load $\geq 0.308$. However, even this Cold Hill chronology loads higher (0.295) than the other genera.

\section{Comparisons of chronologies from different treatments}

In this ad hoc analysis, it is not possible to clearly separate the potential additive effects between sampling strategies and forest conditions. Despite this limitation, we make comparisons to determine if there are substantial differences in radial growth between various combinations of "treatments" (previously cut forests, old-growth forests, randomly selected trees, targeted trees) (Fig. 3). Chronologies from previously cut forests, including some records from randomly selected trees in cut forests, show strong annual correlation with and generally have multiannual coherency with chronologies from oldgrowth forests. Focusing on Quercus and Tsuga chronologies, significant correlation is found between the classic old-growth forest chronologies (Mammoth Caves, Lilley Cornett Woods, and three Blanton Forest collections) and logged forest chronologies (Cold Hill Leucobalanus, London Forest T. canadensis, London Forest Liriodendron, Whittleton Ridge, Floracliff, and Griffith Woods) (Figs. $3 a$ and $3 b$; Table 3). Of note: correlation analysis and PCA both suggest that there is a potential geographic interaction within our network (Tables 2 and 3). Correlations are weaker when comparing chronologies in southern and southeastern Kentucky with collections at the northern end of our network. A similar drop in correlation is apparent from the western portion of our study area versus the eastern portion. Despite this limitation, we find significant 
Fig. 2. New tree-ring chronologies in eastern Kentucky. (a) Blanton Forest Quercus alba, (b) Blanton Forest Quercus montana, (c) Blanton Forest Tsuga canadensis, (d) London Forest T. canadensis, (e) Cold Hill Quercus subgenus Leucobalanus, $(f)$ Floracliff Nature Sanctuary Quercus muehlenbergii, ( $g$ ) Griffith Woods Fraxinus quadrangulata, $(h)$ Griffith Woods $Q$. muehlenbergii, $(i)$ London Forest Liriodendron tulipifera, and $(j)$ Whittleton Ridge $Q$. montana. Each curve has a 9 year spline to reveal multiannual variation in ring index. Dashed horizontal lines represent the mean. The two dashed vertical lines highlight the sudden and extended downturn in ring index during the 1790 s that is only seen in the Inner Bluegrass Region records (Figs. $2 f, 2 g$, and $2 h$ ).
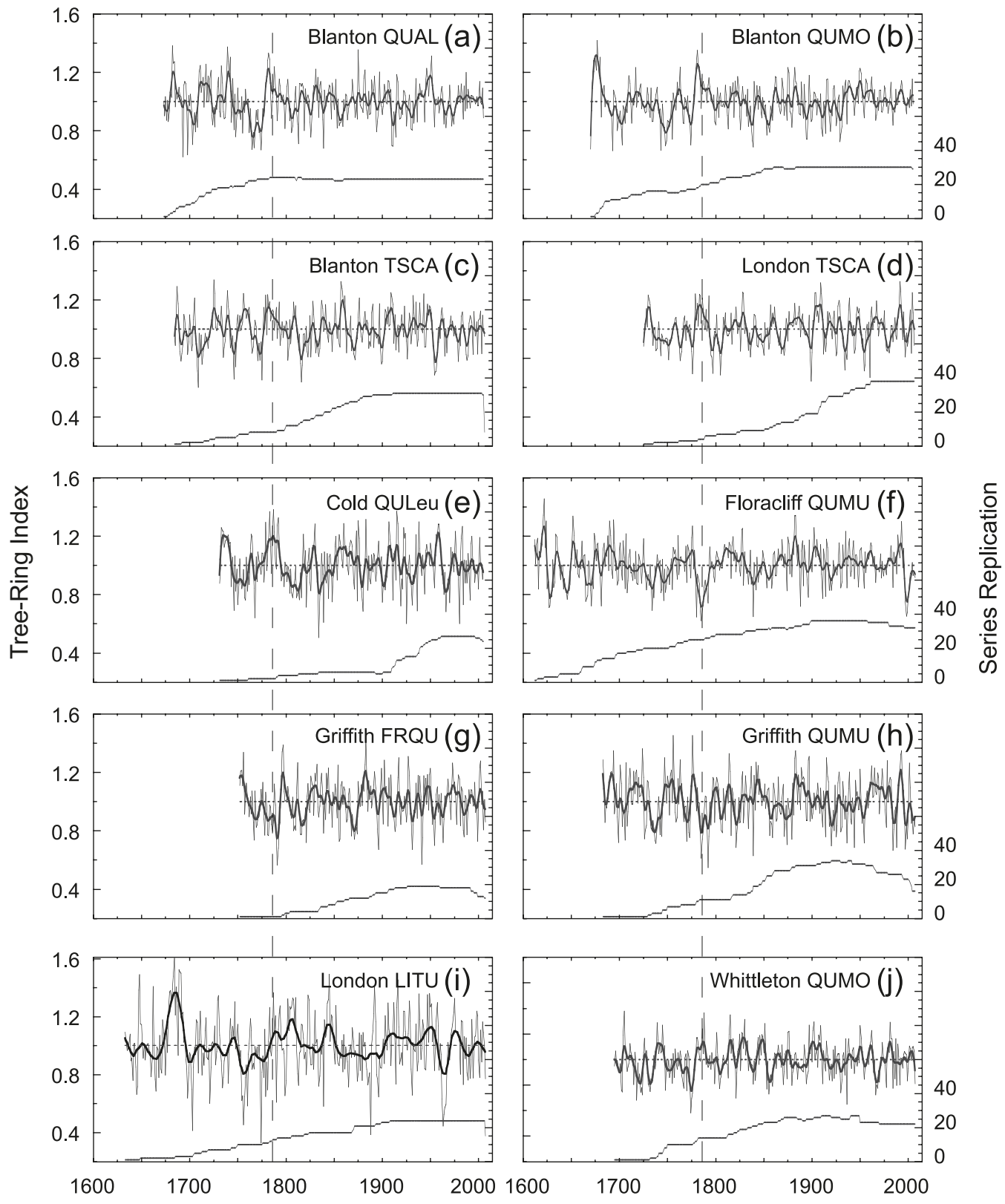

Year

similarities in ring width variation between trees from logged and old-growth forests. Finally, when we combine chronologies from old-growth $(n=5)$ and second-growth forests $(n=$ 7) into a single time series of the first unrotated principal component of PCA for each forest condition, we find a very strong relation in annual variation over the 1796-1982 common period $(r=0.809, p<0.0001$ ) (Fig. 3c).

Comparisons between targeted and random sampling methods gave further insight into the usefulness of the nonclassical tree-ring collections for dendroclimatic purposes. For a fairer comparison with the Cold Hill Leucobalanus chronology, the targeted classical Blanton Forest $Q$. alba and Q. montana collections were combined in ARSTAN using the methods above. Targeted and randomly sampled chronologies are positive and significantly correlated (London Forest T. canadensis versus Blanton Forest T. canadensis, $r=0.472, p<0.0001$; combined Blanton versus Cold Hill Leucobalanus, $r=0.441$, $p<0.0001)$. Despite low replication in the Cold Hill Leuco- 
Table 2. Varimax factor scores for rotated principal component analysis for the new chronologies from eastern Kentucky for the 17962005 common period.

\begin{tabular}{llccc}
\hline Chronology & VF1 & VF2 & VF3 & $\begin{array}{c}\text { Loading on first unrotated } \\
\text { principal component }\end{array}$ \\
\hline Blanton Forest Quercus alba & $\mathbf{0 . 7 5 0}$ & -0.041 & 0.335 & 0.343 \\
Blanton Forest Quercus montana & $\mathbf{0 . 7 8 4}$ & 0.109 & 0.272 & 0.339 \\
Blanton Forest Tsuga canadensis & 0.113 & $\mathbf{0 . 8 6 2}$ & 0.080 & 0.150 \\
London Forest Liriodendron tulipifera & $\mathbf{0 . 7 0 5}$ & 0.087 & -0.104 & 0.223 \\
London Forest Tsuga canadensis & 0.066 & $\mathbf{0 . 8 4 1}$ & 0.153 & 0.134 \\
Cold Hill Quercus subgenus Leucobalanus & $\mathbf{0 . 6 3 7}$ & 0.151 & 0.204 & 0.295 \\
Floracliff Sanctuary Quercus meuhlenbergii & 0.023 & 0.138 & $\mathbf{0 . 7 3 2}$ & 0.341 \\
Griffith Woods Fraxinus quadrangulata & 0.469 & 0.113 & $\mathbf{0 . 6 0 7}$ & 0.219 \\
Griffith Woods Quercus meuhlenbergii & 0.210 & 0.123 & $\mathbf{0 . 8 1 3}$ & 0.308 \\
Whittleton Ridge Quercus montana & 0.536 & -0.040 & 0.522 & 0.320 \\
Lilley Cornett Quercus alba & na & na & na & 0.350 \\
Mammoth Cave Quercus alba & na & na & 0.326
\end{tabular}

Note: Scores $>0.600$ are in bold to emphasize the species level and geographic aspect of the network. The last column shows the loadings of all site chronologies used in this study onto the first unrotated principal component for the 1796-1982 common period. The first unrotated principal component accounts for $40.9 \%$ of the common variance among all 12 chronologies. na, not applicable.

Table 3. Correlations between the ARSTAN chronologies of tree-ring collections in eastern Kentucky.

\begin{tabular}{|c|c|c|c|c|c|c|c|c|c|c|c|}
\hline Blanton QUAL & $0.359 * *$ & - & & & & & & & & & \\
\hline Blanton TSCA & 0.143 & 0.092 & 0.172 & - & & & & & & & \\
\hline London TSCA & 0.047 & 0.116 & 0.214 & $0.513 * *$ & - & & & & & & \\
\hline$\overline{\text { Cold Hill Leuc. }}$. & $0.310 * *$ & $0.408 * *$ & $0.458 * *$ & 0.193 & 0.156 & - & & & & & \\
\hline Griffith QUMU & 0.148 & $0.403 * *$ & $0.384 * *$ & 0.182 & $0.232 *$ & $0.342 * *$ & $0.545 * *$ & $0.460 * *$ & - & & \\
\hline Whittleton QUMO & $0.260 *$ & $0.531 * *$ & $0.440 * *$ & 0.118 & 0.113 & $0.407 * *$ & $0.517 * *$ & $0.291 * *$ & $0.424 * *$ & - & \\
\hline Mammoth QUAL & $0.287 * *$ & $0.477 * *$ & $0.389 * *$ & 0.237 & 0.148 & $0.402 * *$ & $0.410 * *$ & $0.254 *$ & $0.392 * *$ & $0.390 * *$ & - \\
\hline Lilley QUAL & $0.271 * *$ & $0.573 * *$ & $0.469 * *$ & 0.238 & 0.231 & $0.459 * *$ & $0.387 * *$ & 0.197 & $0.298 * *$ & $0.568 * *$ & $0.540 * *$ \\
\hline
\end{tabular}

Note: Correlations are for the 1796-2005 period except for comparisons with Mammoth Cave and Lilley Cornett Woods. The latter chronologies are the only classical dendroclimatic collections in eastern Kentucky and are correlated for the 1796-1985 and 1796-1982 common periods, respectively. See Table 1 for site names. Underlined site names represents randomly sampled trees. See Table 1 and text for more details. Species: LITU, Liriodendron tulipifera; QUAL, Quercus alba; QUMO, Quercuc montana; TSCA, Tsuga candensis; Leuc., Quercus subgenus Leucobalanus and is comprised of QUAL and QUMO; QUMU, Quercus muehlenbergii; FRQU, Fraxinus quadrangulata. Italics, significant at $p<0.05$; bold, significant at $p<0.01$; *significant at $p<0.001 ; * *$ significant at $p<0.0001$.

balanus and London Forest T. canadensis chronologies, there is some temporal coherence in ring width at multiannual to decadal time scales (Figs. $3 a$ and $3 b$ ). Tsuga canadensis chronologies are visually coherent in the latter half of the $1700 \mathrm{~s}$ and from the mid-1800s through the 1970s, while the Quercus chronologies generally show less coherency. The period of low agreement between the Quercus chronologies coincides with the lowest Cold Hill EPS values. Finally, correlating the Blanton Forest Leucobalanus record with the Lilley Cornett and Mammoth Cave Quercus chronologies indicates that, while classical records retain more of the regional signal, differences are small enough to suggest that even records of randomly selected trees in cut forests with low replication over roughly half of their record retain a significant portion of the larger signal. The Blanton Forest Leucobalanus combined record correlates slightly greater than Cold Hill Leucobalanus record versus the Lilley Cornett ( $r=0.476$ versus 0.459$)$ and
Mammoth Cave ( $r=0.453$ versus 0.402$)$ classical collections over the 1796-1982 common period.

\section{Spectral analysis}

Spectral analysis indicates a range of retained power at various frequencies in all 12 chronologies (Fig. 4). Most records have significant spectral power at frequencies of 2.29.4 years and less power beyond 10 years. Collections from intensively logged forests, Cold Hill Leucobalanus and Whittleton Ridge $Q$. montana (Figs. $4 f$ and $4 j$, respectively), have an absence of power at 3-6 year frequencies. Unexpectedly, the two classical collections, Lilley Cornett Woods $Q$. alba and Mammoth Cave National Park $Q$. alba (Figs. $4 k$ and $4 l$, respectively), do not have statistically significant power at low frequency, while two logged forests have significant power at periodicities $>10$ years, Floracliff $Q$. meulenbergii and Whittleton Ridge $Q$. montana (Figs. $4 i$ and $4 j$, respec- 
Fig. 3. Comparison of smoothed curves of (a) Tsuga canadensis, (b) Quercus subgenus Leucobalanus from Cold Hill (dashed line) and Blanton Forest (solid line), and (c) chronologies from previously cut (dashed line) versus oldgrowth forests (solid line). The common period for comparison in Fig. $3 c$ is limited because two collections were made during the 1980s. Each curve was smoothed with a 9 year spline to emphasize multiannual- to decadal-scale variability. Solid horizontal lines represent the mean. The curves in Figs. $3 a$ and $3 b$ contain not only trees from cut forests but also randomly selected trees. See text for more details.
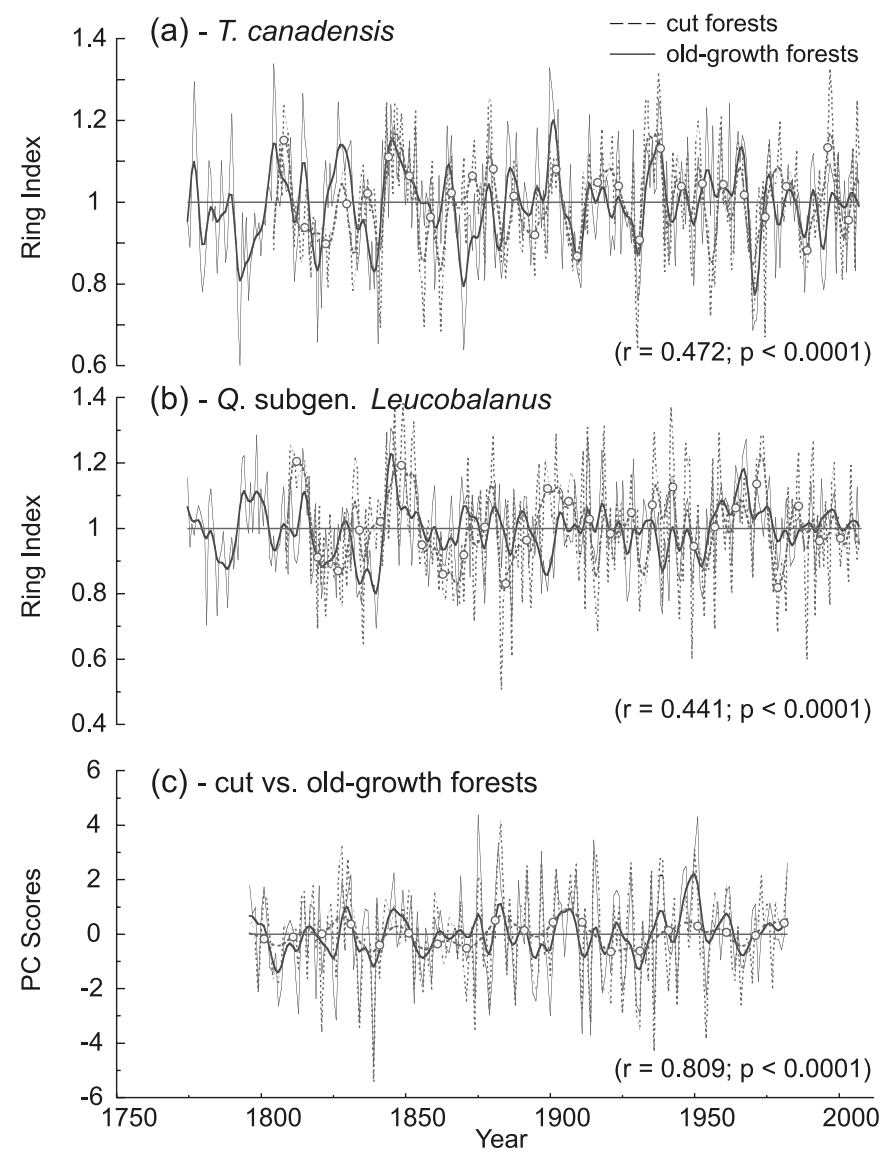

tively). Interestingly, Floracliff $Q$. meulenbergii has a significant peak at 38 years as well as a long-term (or secular) trend at multicentennial periodicities (actual power $=7.668$ versus $90 \%$ confidence limit (CL) criteria $=6.73$ and $95 \% \mathrm{CL}$ criteria $=7.67)$. Similarly, the London Forest L. tulipifera has a peak at 22.8 years, just below the $90 \%$ CL (actual power $=$ 28.532 versus $90 \%$ CL criteria $=28.9$ ). The Mammoth Cave Q. alba also has a peak just below the $90 \%$ CL at 10.8 years $($ actual $=6.44$ versus $90 \% \mathrm{CL}$ criteria $=6.51)$.

The first principal component of the new tree-ring collections in eastern Kentucky has significant power at 2.67.3 years (Fig. 5a). Comparing the spectral properties of the first principal component from previously cut forests and old-growth forest collections indicates similar spectral properties (Figs. $5 b$ and $5 c$ ). While the time series from previously cut forest has less power at 6-7 years compared with the old-growth forest series, it has power at 3.4 years that is absent in the old-growth forest series.

\section{Comparison with the North American Drought Atlas}

When comparing these series of (1) all new chronologies, (2) previously cut forests, and (3) old-growth forests with eastern Kentucky drought, we see less spectral power at lower frequencies than the frequencies in the NADA series but more power at middle frequencies (3-7 years) (Figs. $5 a-5 d$ ). To extend this analysis over a longer time period to test if the shorter period is causing differences in retained periodicity, nested reconstruction techniques (Meko 1997) were employed on the new chronologies and normalized to create $z$-scores from 1633 to 2005 (Supplemental Material). Replication is low for all records in Kentucky prior to 1650 , so comparison of the $z$-scores is limited to 1650-2005. The new long record is significantly correlated with drought $(r=0.723, p=$ 0.0001). Even though spectral analysis indicates that new records have no power at lower frequencies like the NADA drought record, the two series are generally in phase at multiannual periods from 1660 to 2005 (Fig. 6a).

Finally, PCA was used to create a time series of new or rarely used species for dendroclimatology ( $F$. quadrangulata, L. tulipifera, and $Q$. muehlenbergii) to examine their potential for paleoclimatic research. The "new species" chronology correlates at $0.679(p=0.0001)$ against eastern Kentucky drought from 1796 to 2005 (Fig. 6b). Like most of the new records here, spectral analysis of this series reveals several peaks of spectral power at periodicities between 2.5 and 5.6 years (Supplemental Material Fig. S2).

\section{Discussion}

Using a new, independent, and more spatially dense network of eastern Kentucky tree-ring records, we find that composite records drawn from nonclassical records could be useful for reconstructions. Despite the potential that additive impacts from different forest conditions and sampling methods could make a final chronology noisier, our analysis indicates that combinations of trees from preciously cut forests (including randomly selected trees) generally match ring width variation from more classical dendroclimatic collections, chronologies from old-growth forests, and reconstructed drought at 1-7 year time scales. These results suggest that nonclassical records can be useful for reconstructing drought in areas with little oldgrowth forest. These results support the postulation that site selection might not be the most critical aspect of field methods in humid eastern North America (Cook 1982). In fact, these results extend that postulation by showing that trees in heavily cut forests can be of value for reconstructing climate.

Importantly for dendroclimatology, the similarities in annual- to decadal-scale variations in radial growth are encouraging, if not somewhat surprising, given the differing types of field methodologies, forest histories, complex topography, and low replication of some collections between populations nearly $90 \mathrm{~km}$ apart (Fig. 3). If this kind of data is to be used for dendroclimatic studies, it should be combined with data from older trees outside randomly selected plots to ensure better replication in the earlier portions of a chronology. Individual chronologies from nonclassical collections do not appear sufficient enough to retain the larger regional signal on their own (Fig. 3; Tables 2 and 3). Therefore, by utilizing nonclassical records with more classical records, network gaps can be filled to enhance understanding of regional climatic variation (see fig. 5 in Cook et al. 2010). 
Fig. 4. Spectral analysis for all eastern Kentucky tree-ring records. (a) Blanton Forest Quercus alba, (b) Blanton Forest Tsuga canadensis, (c) Blanton Forest Quercus montana, (d) London Forest T. canadensis, (e) Cold Hill Quercus subgenus Leucobalanus, ( $f$ ) London Forest Lirodendron tulipifera, $(g)$ Griffith Woods Quercus muehlenbergii, $(h)$ Griffith Woods Fraxinus quadrangulata, (i) Floracliff Nature Sanctuary Q. muehlenbergii, (j) Whittleton Ridge $Q$. montana, $(k)$ Lilley Cornett Woods $Q$. alba, and $(l)$ Mammoth Cave National Park $Q$. alba. The lower smooth and solid curve on each graph represents the null hypothesis. The dotted smooth curve represents the $90 \%$ confidence limit (CL). The thinner smooth curve above the $90 \%$ $\mathrm{CL}$ is the $95 \% \mathrm{CL}$. The dashed line with circles represents the 99\% CL. Graphs are arranged so spectral frequencies can be compared by species. Spectral analysis was conducted on ring index from 1796 to 2005 except for Lilley Cornett Woods (1796-1982) and Mammoth Cave National Park (1796-1985). Numbers on each panel represent significant periodicities in ring width variation ( $\geq 90 \%$ CL).

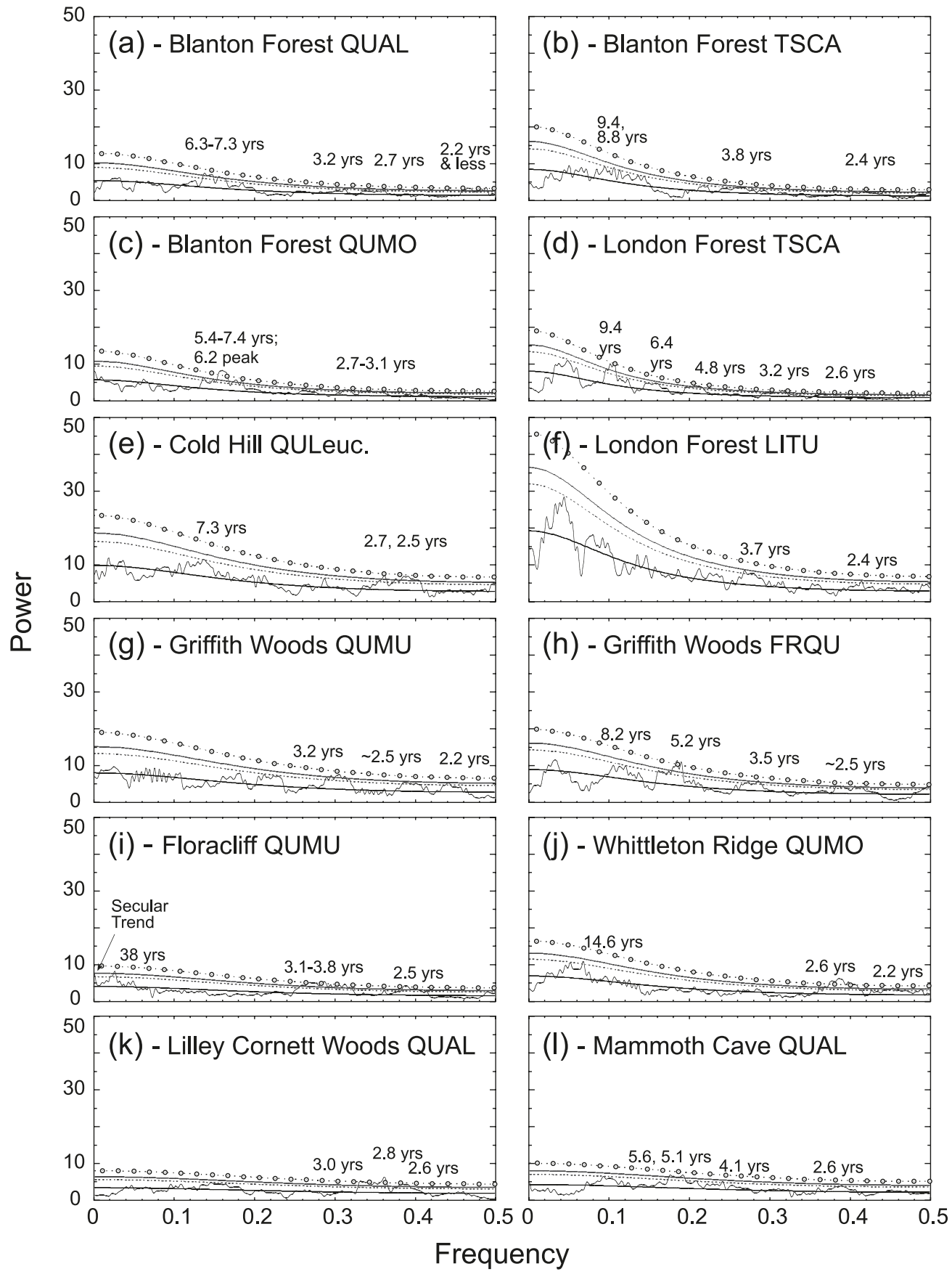

\section{Limitations: longevity, disturbance, and low-frequency information}

One potential limitation for using records from nonclassical dendroclimatic species is that some of these species are perceived to be shorter-lived than traditional species. This is important in at least two ways. First, series composed of shorter segments will limit the maximum wavelength of ring variation, which results in the "segment length curse" (Cook et 
Fig. 5. Spectral analysis for differing types of tree-ring records and drought history in eastern Kentucky. (a) Spectral analysis of the first principal component of the 10 new tree-ring records from 1796 to 2005, (b) spectral analysis of tree-ring records from previously cut forests from 1796 to 1982, (c) spectral analysis of tree-ring records from old-growth forests from 1796 to 1982 , (d) spectral analysis of the eastern Kentucky North American Drought Atlas from 1796 to 2005, (e) spectral analysis of the average North American Drought Atlas grid points in eastern Kentucky from 1633 to 2005, and $(f)$ spectral analysis of z-scores of the new tree-ring records from eastern Kentucky from 1633 to 2005. Confidence limits and significant periodicities are the same as in Fig. 4.

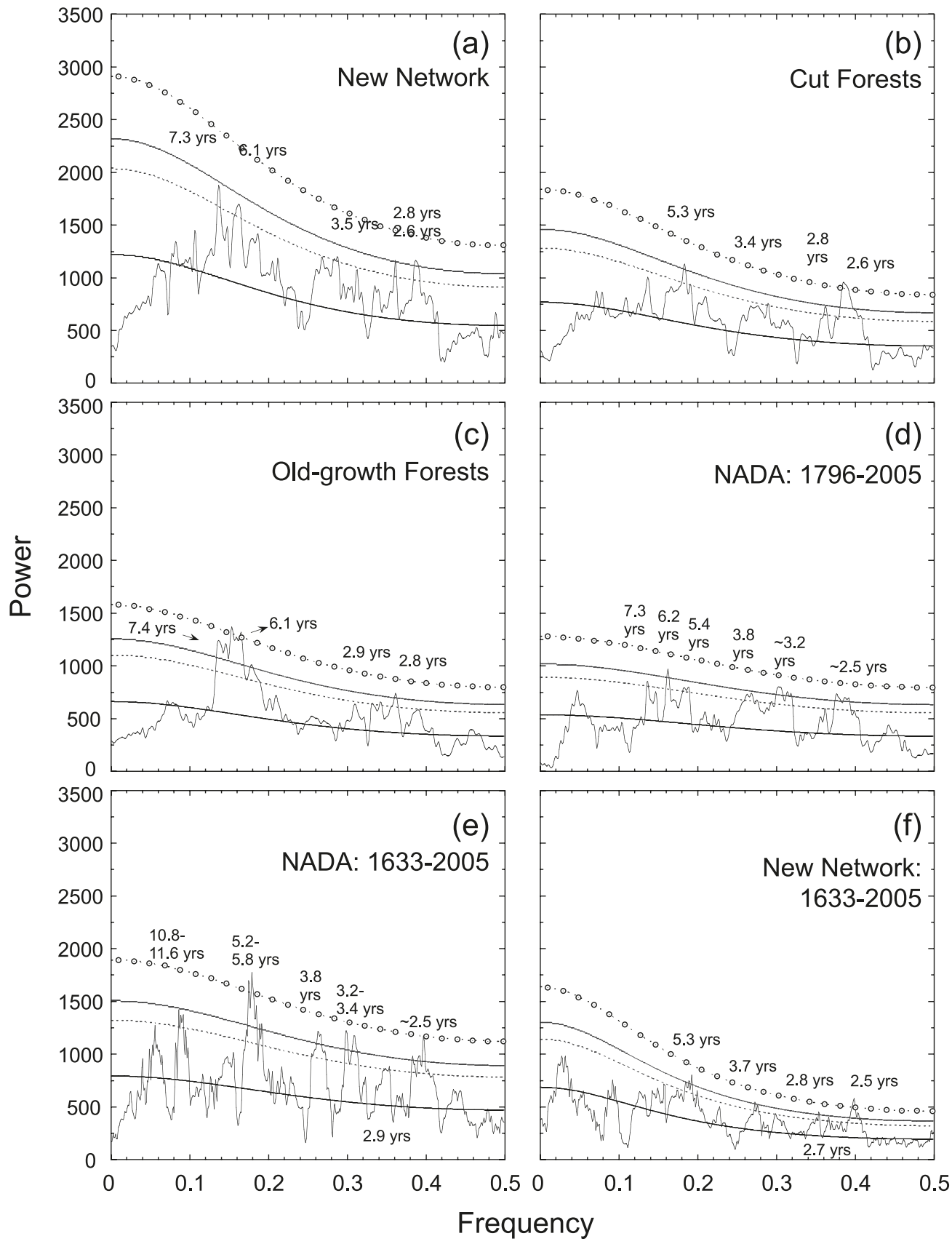

al. 1995). Climatic reconstructions composed of records biased with this "curse" would have less recoverable low-frequency information. Second, the length of the shortest chronology can limit the final length of a climatic reconstruction. The nested methodology used here, however, makes it possible to include shorter records in the development of climatic reconstructions (Cook et al. 2003). Just as important, recent evidence indicates that some short-lived species live longer than previously thought (Pederson et al. 2007; Pederson 2010). A good example of this is L. tulipifera, where trees $>400$ years not too unusual, the current maximum age is at 509 years, and a maximum age of 600 years seems likely (Pederson 2010; Pederson et al. 2012a). If greater longevities are found in more species, then species longevity will be much less of a problem.

Another problem related to tree age is the perception that forests disturbed by logging do not have old trees. Our inves- 
Fig. 6. Comparison of eastern Kentucky drought from the North American Drought Atlas (solid line with a black line highlighting multiannual- to decadal-scale variability) and (a) z-scores of the new tree-ring records from eastern Kentucky (dashed line and a gray line with dotted circles) from 1633 to 2005 and $(b) z$-scores derived from tree-ring records of rarely used species for hydroclimatic studies (dashed line and a gray line with dotted circles) from 1796 to 2005 . All curves were smoothed with a 9 year spline. The horizontal line represents the mean.

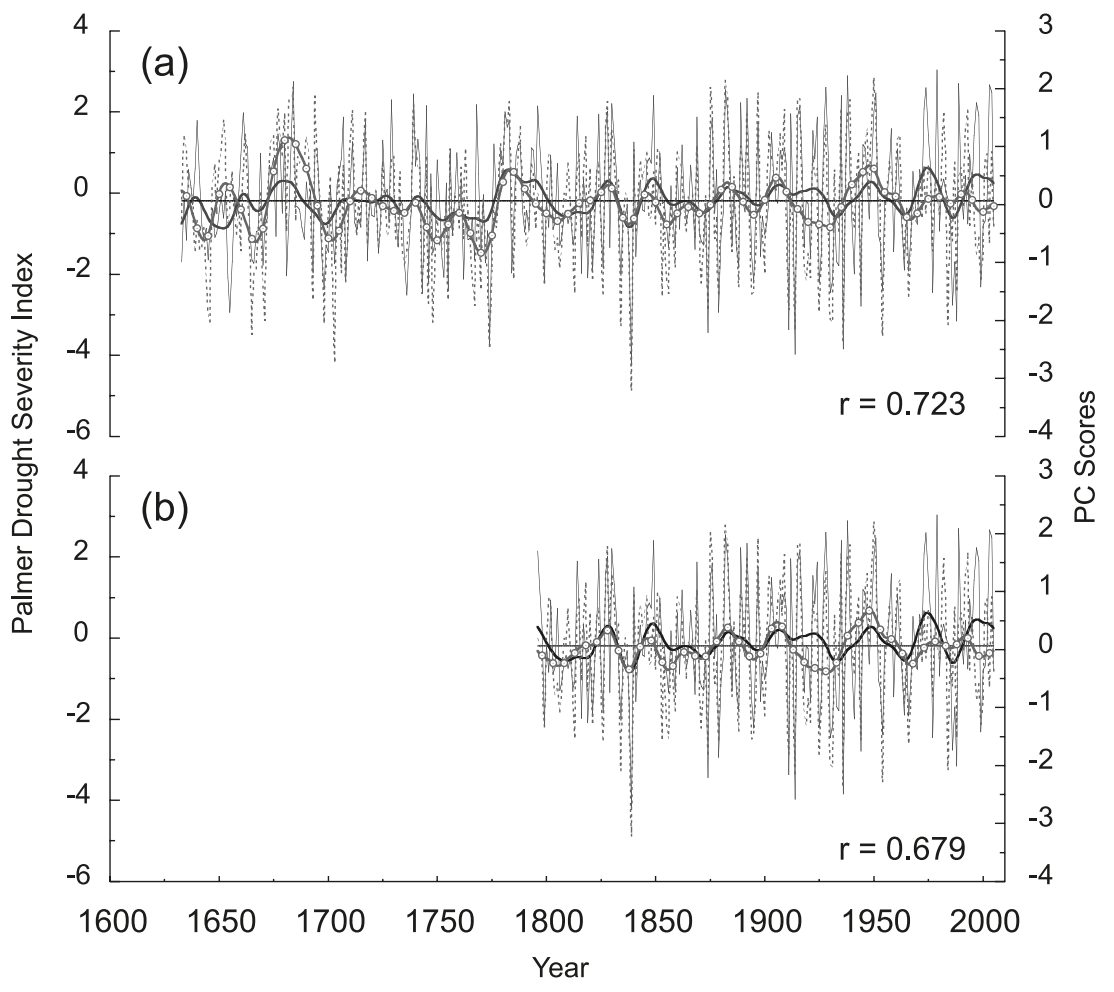

tigations in eastern Kentucky have revealed the presence of old trees in previously cut forests, including forests that have been likely cut at least twice since the late 19th century. Many forests in the eastern United States were high-graded, or cut without using professional forest management techniques (i.e., cut without regard for future regeneration and sustainability), to gain short-term economical returns (Frothingham 1931). Often, the least valuable trees (e.g., hollow, poor stem form, undesirable timber species) were left in the forest. Some of these trees can be quite old (Pederson 2010). The heavily cut Cold Hill forest, characterized by a predominance of trees dating between 1880 and 1940, had several Q. alba dating to the $1700 \mathrm{~s}$. Given that $Q$. alba is a highly valued timber species, this discovery was surprising. Similarly, the forest below Cold Hill, Cane Creek Wildlife Management Area, contains many trees dating to the 1600s and 1700s despite evidence of logging (Tackett 2012). In fact, in all of the previously cut forests, we found older trees without spending an inordinate amount of time searching for old trees. The best example might be the approximately 400 year old yellow buckeye (Aesculus flava Sol.) in the cut forests near Whittleton Ridge (Cooper 2011). A thorough investigation using search images of old trees (Stahle and Chaney 1994; Pederson 2010) in regions with little old-growth forest could have a significant payoff for dendroclimatic research.

Disturbance frequency in nonclassical forests, however, could be a less surmountable limitation. Land-use legacies could degrade the climatic signal in surviving trees (Gunnarson et al. 2012). We see some indication of this here. The
Quercus chronology that loaded the lowest on the first unrotated principal component is composed of trees from the midst of one of the most repeatedly cut forests in our study (Table 2). Teasing out confounding effects, such as randomly selected trees or canopy status, in our study here, however, is impossible. A study on the impact of single-tree selection, however, suggests that surviving trees $>5 \mathrm{~m}$ from a stump generally contain the larger-scale climate signal (Esper et al. 2012). We also note that collections in our study from the most repeatedly and intensively logged forests generally have an absence of power at low frequencies (Fig. 4e), although there are exceptions (Figs. $4 i$ and $4 j$ ). Low-frequency signals in tree-ring records from heavily cut forests could be lost due to the greater frequency of changes in competitive pressure compared with old-growth forests (although age structure of these forests can revive the segment length curse, too). Trees from old-growth forests experience substantial changes in competitive pressure that are not dissimilar to trees left in forests during logging (Rentch et al. 2002). What is dissimilar between these land-use histories is most often the frequency and spatial scale of disturbance since the 19th century. Logging rotations often occurred every 30-50 years at a spatial scale that impacts most of the forest. The frequency and spatial intensity of wide-scale logging that occurred around the turn of the 19th century do not match the typical gap-dynamics disturbance regime of closed-canopy forests. Thus, logged forests originated from this era would have more stand-wide changes in competitive pressure. In this scenario, the frequent and spatially pervasive change in competitive pressure could override decadal to 
multidecadal changes in climate and force the detrending of tree rings from these forests to reduce the influence of changes in competition in such a way that it reduces the low-frequency signal.

Differences in the retention of low-frequency signals between reconstructed drought and chronologies in our network could be the result of standardization. To test this, we experimented with restandardizing the entire network using the signal-free method (Melvin and Briffa 2008; Supplemental Material). The signal-free method was developed to help retain spectral power lost through standardization methods that employ varying lengths of bandpass filters or splines. While a spectral analysis of the new network using some chronologies developed through the signal-free method improved the spectral power at lower frequencies, none of these lower frequencies were statistically significant (Supplemental Material Fig. S3). This analysis indicates that tree-ring data from nonclassical locations might have limitations at retaining lowfrequency information. Therefore, there is a great need to develop new standardization techniques for trees with shorter segments from frequently disturbed, high-density forests.

\section{Genera and patterns of radial increment}

Through correlation and spectral analysis, we found that genera matter in long-term ring width variation. Quercus and Tsuga chronologies correlated better with chronologies of the same species or subgenus across the region than chronologies of different species in the same forest. This finding supports tree-ring investigations of phylogenetic signals (Graumlich 1993; Cook et al. 2001). Tsuga canadensis appears to have the most unique pattern of ring width variation in our network. The impending functional extinction of $T$. canadensis due to the hemlock adelgid will bring about the loss of a strong and specific dendroclimatic signal because T. canadensis is one of the more important species for the NADA.

While we did not sample a species that could completely replace T. canadensis for dendroclimatic research, we did find three underutilized species that contain hydroclimatic information (Fig. 6b). It is not surprising that a drought-deciduous species like L. tulipifera tracks hydroclimate. This climatic sensitivity allows it to contribute to reconstructions of hydroclimatic, including three recent reconstructions (Maxwell et al. 2011; Pederson et al. 2012a, 2012b). Two other species, F. quadrangulata (for which this seems to be the first tree-ring chronology of this species) and $Q$. muehlenbergii (a species not present in the ITRDB), significantly contribute to the "new species chronology" that is significantly correlated with reconstructed drought from 1796 to 2005 (Fig. 6b). That the Griffith Woods $F$. quadrangulata and $Q$. muehlenbergii collections are drought sensitive is important because both chronologies are drawn from open-grown forests growing on relatively rich soils in a humid region (Supplemental Material). The finding that the radial increment of trees in a humid environment and low-density forests varied with drought for over 200 years is not expected given that trees in thinned forests are less water stressed (e.g., Martín-Benito et al. 2010). Combined with our findings here, results indicating that low-density forests are less water stressed suggest that these species would hypothetically have an even stronger relationship to drought in denser forests.

\section{Drought as a strong factor of stem growth}

Our findings that trees in nonclassical forests have strong drought signals, even in low-density forests, have broad implications. Because a substantial proportion of the annual to multiannual variation in tree growth from trees across canopy strata is controlled by drought over the last 210-346 years (once important factors like competition are reduced), we conclude that the growth of most trees is strongly related to drought variation. These results support evidence since 1920 indicating that water stress is an important limiting factor for trees from a range of species not growing on classic dendroclimatic sites (e.g., Douglass 1920; Schumacher and Day 1939; Graumlich 1993; Orwig and Abrams 1997; Cook et al. 2001; LeBlanc and Terrel 2001; Takahashi et al. 2003; Piovesan et al. 2005; Tardif et al. 2006). This is important because it is often perceived that drought is not important to tree growth in humid environments (e.g., McMahon et al. 2010). Our evidence extends this knowledge beyond most tree-ring collections: even trees growing in open woodlands or randomly selected trees $\geq 10 \mathrm{~cm}$ DBH in moist ravines or "typical" upland forests have a significant relationship to drought (Fig. 6; Supplemental Material). These results indicate that drought is not only an important factor of forests on dry or more classic dendrohydroclimatic sites, but that it is a significant, long-term factor in humid regions.

\section{Summary}

Results here indicate that nonclassical tree-ring data from previously cut forests or tree-ring records collected using nontraditional field methods could have some utilization for reconstructing climate. We found striking similarity in radial growth across a topographically diverse region between classical and nonclassical collections and nonclassical tree-ring records and reconstructed drought at annual to decadal time scales. Such data will be most valuable in areas with little old-growth forest. If these patterns are replicated in other regions, the next phase of paleoclimatic research could utilize existing or future dendroecological tree-ring data sets to build networks with greater spatial network density and species diversity for areas with exiguous old-growth forest. Perhaps most importantly, our results indicate that drought is an important driver of radial growth of forest interior trees in humid environments.

\section{Acknowledgements}

This research was funded through the KSNPC Small Grant Program (N.P.), the USFS Southern Research Station (N.P. and S.C.), Kentucky Academy of Sciences (A.C.), EKU University Resesearch Committee (K.T.), and Kentucky Natural History Society (A.C. and K.T.). Thanks to J. Bender, M. Evans, and K. Napier for permission to sample in Blanton Forest, Floracliff Sanctuary, and Tom Dorman, J. Strojan, P. Rousopoulos, and D. Taylor of the DNNF for permission to sample in the Cold Hill District, Rock Creek Research Natural Area, and on Whittleton Ridge, C. Cook for crossdating and measuring many of the Blanton Forest samples, C. Cook, T. Evans, R. Gaines and son, C. Lattin, and L. Watt for field assistance, EKU Fall 2009 Forest Ecology class for coring at Tom Dorman, M. Flanary and Kentucky Natural Lands Trust for additional logistical support, C. Leland for map preparation, Drs. Cook, Orwig, and van de Gevel for their conversations, three anonymous reviewers who improved this analysis 
and manuscript, and K. Ross and C. Leland for assistance in manuscript preparation. Lamont contribution 7599.

\section{References}

Black, B.A., Colbert, J.J., and Pederson, N. 2008. Relationships between radial growth rates and lifespan within North American tree species. Ecoscience, 15(3): 349-357. doi:10.2980/15-3-3149.

Cook, E.R. 1982. Tree-ring data networks: comment. In Climate from tree rings. Edited by M.K. Hughes, P.M. Kelly, J.R. Pilcher, and V.C. LaMarche, Jr. Cambridge University Press, London, U.K. pp. 6-7.

Cook, E.R. 1985. A time series analysis approach to tree ring standardization. The University of Arizona, Tucson, Az.

Cook, E., and Jacoby, G., Jr. 1977. Tree-ring-drought relationships in the Hudson Valley, New York. Science, 198(4315): 399-401. doi:10.1126/science.198.4315.399. PMID:17809441.

Cook, E.R., and Kairiukstis, L.A. (Editors). 1990. Methods of dendrochronology: applications in the environmental sciences. Kluwer Academic, Dordrecht, The Netherlands.

Cook, E.R., and Krusic, P.J. 2011. Software [online]. Available from http://www.ldeo.columbia.edu/tree-ring-laboratory/resources/ software [accessed 29 November 2011].

Cook, E.R., and Pederson, N. 2011. Uncertainty, emergence, and statistics in dendrochronology. In Dendroclimatology: progress and prospects, developments in paleoecological research. Vol. 11. Edited by M.K. Hughes, T.W. Swetnam, and H.F. Diaz. Springer, New York. pp. 77-112.

Cook, E.R., and Peters, K. 1981. The smoothing spline: a new approach to standardizing forest interior tree-ring width series for dendroclimatic studies. Tree-Ring Bull. 41: 45-53.

Cook, E.R., Briffa, K.R., Meko, D.M., Graybill, D.A., and Funkhouser, G. 1995. The "segment length curse" in long tree-ring chronology development for palaeoclimatic studies. Holocene, 5(2): 229-237. doi:10.1177/095968369500500211.

Cook, E.R., Glitzenstein, J.S., Krusic, P.J., and Harcombe, P.A. 2001. Identifying functions groups of trees in west Gulf Coast forests (USA): a tree-ring approach. Ecol. Appl. 11(3): 883-903. doi: 10.1890/1051-0761(2001)011[0883:IFGOTI]2.0.CO;2.

Cook, E.R., Krusic, P.J., and Jones, P.D. 2003. Dendroclimatic signals in long tree-ring chronologies from the Himalayas of Nepal. Int. J. Climatol. 23(7): 707-732. doi:10.1002/joc.911.

Cook, E., Seager, R., Heim, R.R.J., Jr., Vose, R.S., Herweijer, C., and Woodhouse, C.A. 2010. Megadroughts in North America: placing IPCC projections of hydroclimatic change in a longterm palaeoclimate context. J. Quat. Sci. 25(1): 48-61. doi: 10.1002/jqs. 1303.

Cooper, A.M. 2011. Age, forest structure, and disturbance history of five potential old-growth forests in eastern Kentucky's Cumberland Plateau. M.Sc. thesis, Department of Biological Sciences, Eastern Kentucky University, Richmond, Ky.

Davis, M.B. (Editor). 1996. Eastern old-growth forests: prospects for rediscovery and recovery. Island Press, Washington, D.C.

Davis, S.C., Hessl, A.E., Scott, C.J., Adams, M.B., and Thomas, R.B. 2009. Forest carbon sequestration changes in response to timber harvest. For. Ecol. Manag. 258(9): 2101-2109. doi:10.1016/ j.foreco.2009.08.009.

Di Filippo, A., Biondi, F., Maugeri, M., Schirone, B., and Piovesan, G. 2012. Bioclimate and growth history affect beech lifespan in the Italian Alps and Apennines. Glob. Change Biol. 18(3): 960-972. doi:10.1111/j.1365-2486.2011.02617.x.
Douglass, A.E. 1920. Evidence of climatic effects in the annual rings of trees. Ecology, 1(1): 24-32. doi:10.2307/1929253.

Druckenbrod, D.L., and Shugart, H.H. 2004. Forest history of James Madison's Montpelier plantation. J. Torrey Bot. Soc. 131(3): $204-$ 219. doi: $10.2307 / 4126951$.

Esper, J., Benz, M., and Pederson, N. 2012. Influence of wood harvest on tree-ring time-series of Picea abies in a temperate forest. For. Ecol. Manag. 284: 86-92.

Friedman, J.H. 1984. A variable span smoother [online]. Available from http://www.dtic.mil/cgi-bin/GetTRDoc?AD=ADA148241\& Location $=\mathrm{U} 2 \& d$ oc $=$ GetTRDoc.pdf [accessed 22 February 2012].

Frothingham, E.H. 1931. Timber growing and logging practice in the southern Appalachian region. U.S. Dep. Agric. Tech. Bull. 250.

García-Suárez, A.M., Butler, C.J., and Baillie, M.G.L. 2009. Climate signal in tree-ring chronologies in a temperate climate: a multispecies approach. Dendrochronologia, 27(3): 183-198. doi: 10.1016/j.dendro.2009.05.003.

Graumlich, L. 1993. Response of tree growth to climatic variation in the mixed conifer and deciduous forests of the upper Great Lakes region. Can. J. For. Res. 23(2): 133-143. doi:10.1139/x93-020.

Gunnarson, B.E., Josefsson, T., Linderholm, H.W., and Östlund, L. 2012. Legacies of pre-industrial land use can bias modern tree-ring climate calibrations. Clim. Res. 53(1): 63-76. doi:10.3354/ cr01083.

Hart, J.L., Clark, S.L., Torreano, S.J., and Buchanan, M.L. 2012. Composition, structure, and dendroecology of an old-growth Quercus forest on the tablelands of the Cumberland Plateau, USA. For. Ecol. Manag. 266: 11-24. doi:10.1016/j.foreco.2011.11.001.

Hessl, A., and Pederson, N. 2013. Hemlock Legacy Project (HeLP): a paleoecological requiem for eastern hemlock. Prog. Phys. Geogr. In press.

Holmes, R.L. 1983. Computer-assisted quality control in tree-ring dating and measurement. Tree-Ring Bull. 43(1): 69-78.

Jones, R.L. 2005. Plant life of Kentucky: an illustrated guide to the vascular flora. The University Press of Kentucky, Lexington, Ky.

LeBlanc, D., and Terrel, M. 2001. Dendroclimatic analyses using Thornthwaite-Mathertype evapotranspiration models: a bridge between dendroecology and forest simulation models. Tree-Ring Res. 57(1): 55-66.

Mann, M.E., and Lees, J.M. 1996. Robust estimation of background noise and signal detection in climatic time series. Clim. Change, 33(3): 409-445. doi:10.1007/BF00142586.

Martín-Benito, D., Del Río, M., Heinrich, I., Helle, G., and Cañellas, I. 2010. Response of climate-growth relationships and water use efficiency to thinning in a Pinus nigra afforestation. For. Ecol. Manag. 259(5): 967-975. doi:10.1016/j.foreco.2009.12.001.

Maxwell, R.S., Hessl, A.E., Cook, E.R., and Pederson, N. 2011. A multispecies tree ring reconstruction of Potomac River streamflow (950-2001). Water Resour. Res. 47(5): 1-12. doi:10.1029/ 2010WR010019.

McEwan, R.W., and McCarthy, B.C. 2008. Anthropogenic disturbance and the formation of oak savanna in central Kentucky, USA. J. Biogeogr. 35(5): 965-975. doi:10.1111/j.1365-2699.2007. 01857.x.

McMahon, S.M., Parker, G.G., and Miller, D.R. 2010. Evidence for a recent increase in forest growth. Proc. Natl. Acad. Sci. U.S.A. 107(8): 3611-3615. doi:10.1073/pnas.0912376107. PMID:20133710.

Meko, D. 1997. Dendroclimatic reconstruction with time varying predictor subsets of tree indices. J. Clim. 10(4): 687-696. doi: 10.1175/1520-0442(1997)010<0687:DRWTVP>2.0.CO;2.

Melvin, T., and Briffa, K. 2008. A "signal-free" approach to dendro- 
climatic standardisation. Dendrochronologia, 26(2): 71-86. doi: 10.1016/j.dendro.2007.12.001.

Orwig, D.A., and Abrams, M.D. 1997. Variation in radial growth responses to drought among species, site, and canopy strata. Trees (Berl.), 11(8): 474-484. doi:10.1007/s004680050110.

Pederson, N. 2010. External characteristics of old trees in the Eastern Deciduous Forest. Nat. Areas J. 30(4): 396-407. doi:10.3375/ 043.030.0405.

Pederson, N., Cook, E.R., Jacoby, G.C., Peteet, D.M., and Griffin, K.L. 2004. The influence of winter temperatures on the annual radial growth of six northern range margin tree species. Dendrochronologia, 22(1): 7-29. doi:10.1016/j.dendro.2004.09.005.

Pederson, N., D'Amato, A.W., and Orwig, D.A. 2007. Central hardwood natural history from dendrochronology: maximum ages of rarely studied species. Proceedings of the 15th Central Hardwood Conference, University of Tennessee, Knoxville, Tenn., 27 February - 1 March 2006. U.S. For. Serv. e-Gen. Tech. Rep. SRS-101.

Pederson, N., Bell, A.R., Knight, T.A., Leland, C., Malcomb, N., Anchukaitis, K.J., Tackett, K., Scheff, J., Brice, A., Catron, B., Blozan, W., and Riddle, J. 2012a. Long-term perspective on a modern drought in the American Southeast. Environ. Res. Lett. 7(1). doi:10.1088/1748-9326/7/1/014034.

Pederson, N., Bell, A.R., Cook, E.R., Lall, U., Devineni, N., Seager, R., Eggelston, K., et al. 2012b. Is an epic pluvial masking the water insecurity of the Greater New York City Region? J. Climatol. In press. doi:10.1175/JCLI-D-11-00723.1.

Piovesan, G., Biondi, F., Bernabei, M., Difilippo, A., and Schirone, B. 2005. Spatial and altitudinal bioclimatic zones of the Italian peninsula identified from a beech (Fagus sylvatica L.) tree-ring network. Acta Oecol. 27(3): 197-210. doi:10.1016/j.actao. 2005.01.001.

Preisendorfer, R.W., Zwiers, F.W., and Barnett, T. 1981. Foundations of principal components selection rules. SIO Reference Series 81, 4 May 1981 [online]. Available from http://gate1.baaqmd.gov/pdf/ 0543_Foundations_Principal_Component_Selection_Rules_ University_California_San_Diego_1981.pdf.

Rentch, J.S., Desta, F., and Miller, G.W. 2002. Climate, canopy disturbance, and radial growth averaging in a second-growth mixed-oak forest in West Virginia, U.S.A. Can. J. For. Res. 32(6): 915-927. doi:10.1139/x02-016.

Richman, M.B. 1986. Rotation of principal components. J. Climatol. 6(3): 293-335. doi:10.1002/joc.3370060305.

Schumacher, F.X., and Day, B.B. 1939. The influence of precipitation upon the width of annual rings of certain timber trees. Ecol. Monogr. 9(4): 387-429. doi:10.2307/1943279.

Schweitzer, C.J., Clark, S., Gaines, G., Finke, P., Gottschalk, K., and Loftis, D. 2008. Integrating land and resource management plans and applied large-scale research on two national forests. In Integrated Restoration of Forested Ecosystems to Achieve Multiresource Benefits: Proceedings of the 2007 National Silviculture Workshop. Edited by R.L. Deal. U.S. For. Serv. Gen. Tech. Rep. PNW-733. pp. 127-134.

Stahle, D.W., and Chaney, P.L. 1994. A predictive model for the location of ancient forests. Nat. Areas J. 14(3): 151-158.

Stahle, D.W., and Cleaveland, M.K. 1988. Texas drought history reconstructed and analyzed from 1698 to 1980. J. Clim. 1(1): 59-74. doi:10.1175/1520-0442(1988)001<0059:TDHRAA $>$ 2.0.CO;2.

Stahle, D.W., and Cleaveland, M.K. 1992. Reconstruction and analysis of spring rainfall over the southeastern US for the past 1000 years. Bull. Am. Meteorol. Soc. 73(12): 1947-1961. doi: 10.1175/1520-0477(1992)073<1947:RAAOSR > 2.0.CO;2.

Tackett, K. 2012. Forest dynamics of two old hemlock-mixed mesophytic forests. M.Sc. thesis, Department of Biological Sciences, Eastern Kentucky University, Richmond, Ky.

Takahashi, K., Azuma, H., and Yasue, K. 2003. Effects of climate on the radial growth of tree species in the upper and lower distribution limits of an altitudinal ecotone on Mount Norikura, central Japan. Ecol. Res. 18(5): 549-558. doi:10.1046/j.1440-1703.2003. 00577.x.

Tardif, J.C., Conciatori, F., Nantel, P., and Gagnon, D. 2006. Radial growth and climate responses of white oak (Quercus alba) and northern red oak (Quercus rubra) at the northern distribution limit of white oak in Quebec, Canada. J. Biogeogr. 33(9): 1657-1669. doi:10.1111/j.1365-2699.2006.01541.x. 


\section{Supplemental Material}

\section{Additional Site History Information:}

Angel Hollow, a hemlock-dominated, mixed-mesophytic forest, contains old trees and is located near the Cold Hill, Cane and Rock Creek study sites in the London District of the Daniel Boone National Forest (Figure 1). Sampled using the point-center quarter method, the nearest tree at each point within two of the alternating quarters was cored twice to investigate tree age structure (Cooper 2011).

Blanton Forest, a reserve purchased by the Kentucky Natural Lands Trust and managed by the Kentucky State Nature Preserves Commission (KSNPC), is on Pine Mountain, a 200 km long ridge running southwest to northeast across southeastern Kentucky in the Cumberland Mountain Province. Of Blanton Forest's 1264 ha, approximately 67\% is old-growth primary forest. Q. alba and $Q$. montana were sampled across most of the 800 ha of old-growth forest on the upper slopes of Blanton Forest. T. canadensis was sampled in the upper portions of the Watts Creek watershed and in an unnamed creek watershed east of Watts Creek. Management restrictions limited coring in Blanton Forest to 48 trees from three species.

Floracliff Nature Sanctuary, a Kentucky state nature preserve managed by the KSNPC, is located in the located Inner Bluegrass physiographic province. Management restrictions limited coring in at Floracliff to 20 trees.

Of the older-looking canopy trees at Griffith Woods in the canopy that would be suitable for 
dendrochronological investigation, we focused on $F$. quadrangulata and $Q$. muehlenbergii. Management restrictions of the preserve, currently owned by Kentucky Fish and Wildlife, limited the coring of 20 trees per species

Several study sites fall within the southern portion of the London Ranger District of the Daniel Boone National Forest (DBNF) at Cold Hill. The general area is composed of a wide range of upland and ravine mixed forests within the Cumberland Plateau. On top of the Cumberland Plateau at Cold Hill, Q. alba and Q. montana trees were sampled in previously-cut, secondgrowth forest. The record from on top of the Cold Hill plateau was obtained from systematically placed vegetation plots within a large-scale silvicultural study designed to study methods of maintaining the oak component (Schweitzer et al. 2008). Cores were collected prior to implementation of silvicultural treatments. Experimental units were assigned at random except where administrative restrictions existed.

In a northern ravine of the Cane Creek watershed, in the southern portion of the Cold Hill just below the Cold Hill plateau site, T. canadensis and Liriodendron tulipifera were sampled in plots distributed throughout the ravine bottom. The plots from which the ravine records were created were established using latitudinal and longitudinal coordinates prior to entering the field (Tackett 2012).

Rock Creek Research Natural Area is in the southern portion of the London District of the DBNF on top of the Cumberland Plateau (Thompson et al. 2000). T. canadensis and L. tulipifera were sampled in plots located in the 77 ha RCRNA ravine. Plots were chosen throughout the ravine 
bottom prior to entering the field using latitudinal and longitudinal coordinates from topographical maps.

Tom Dorman State Nature Preserve, managed by the KSNPC, is located in the located on the outer edge of the Inner Bluegrass physiographic province. Management restrictions limited coring in the preserve to 20 trees.

Whittleton Ridge is a second-growth forest on the Cumberland Plateau in the in the DBNF within the Red River Gorge (Figure S1). Q. montana was sampled from the cliff margins on Whittleton Ridge. The sampled trees from Whittleton Ridge also had characteristics of old angiosperm trees (Pederson 2010) suggesting these trees were left uncut due to 'poor' growth form. 

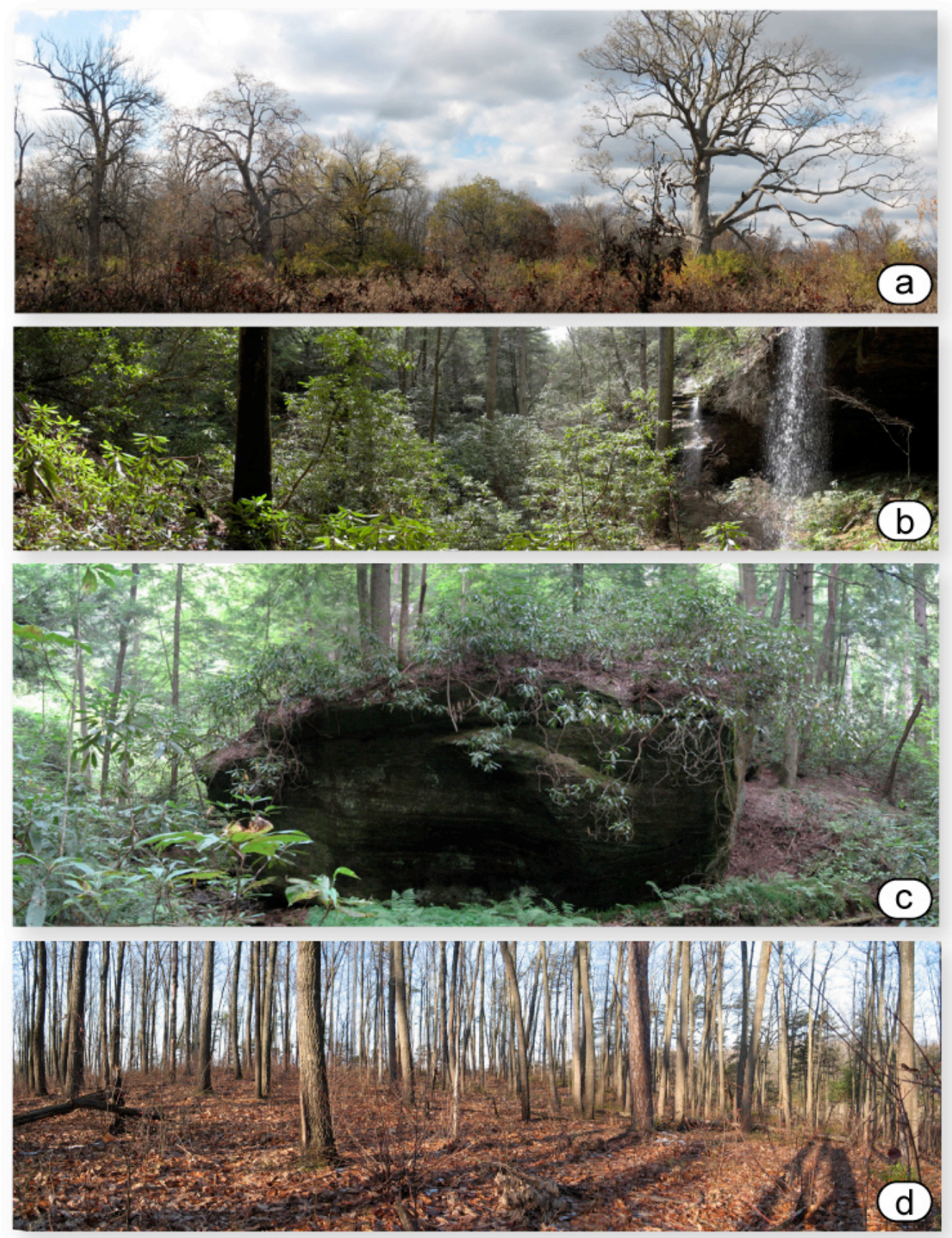

Picture S1 - Scenes from the (a) open woodlands at Griffith Woods with F. quadrngulata (far 1ft) and Q. muehlenbergii (large tree, rt); (b) Rock Creek Research Natural Area - mesophytic forest with Rhododendron understory; (c) the mesophytic forest at Angel Hollow with Rhododendron growing on a rock; and (d) second-growth forest at Whittleton Ridge. Photos: N. Pederson. 


\section{Creation of the 1633-2005 time-series from new chronologies}

The nested technique is an iterative process to fully utilize collection of records with different lengths (Meko 1997, Cook et al. 2003). Here, a PCA was conducted to make the first nest that represented the common period of all collections (1752-2005). The youngest chronology was dropped from the network, Griffith Woods F. quadrangulata, and a PCA was performed on the second nest. This was repeated until two chronologies remained at $1633 \mathrm{CE}$. PC scores from the first PC of each nest were normalized and then the unique periods from each nest were spliced together so that the new collection chronology covers 1633-2005. This new record contains none of the tree ring records used in NADA. Like the whole network PCA and RPCA, all chronologies loaded positively onto the first PC. 


\section{Spectral Analysis Results of PC Scores from 'New' Potential Dendroclimatic Species}

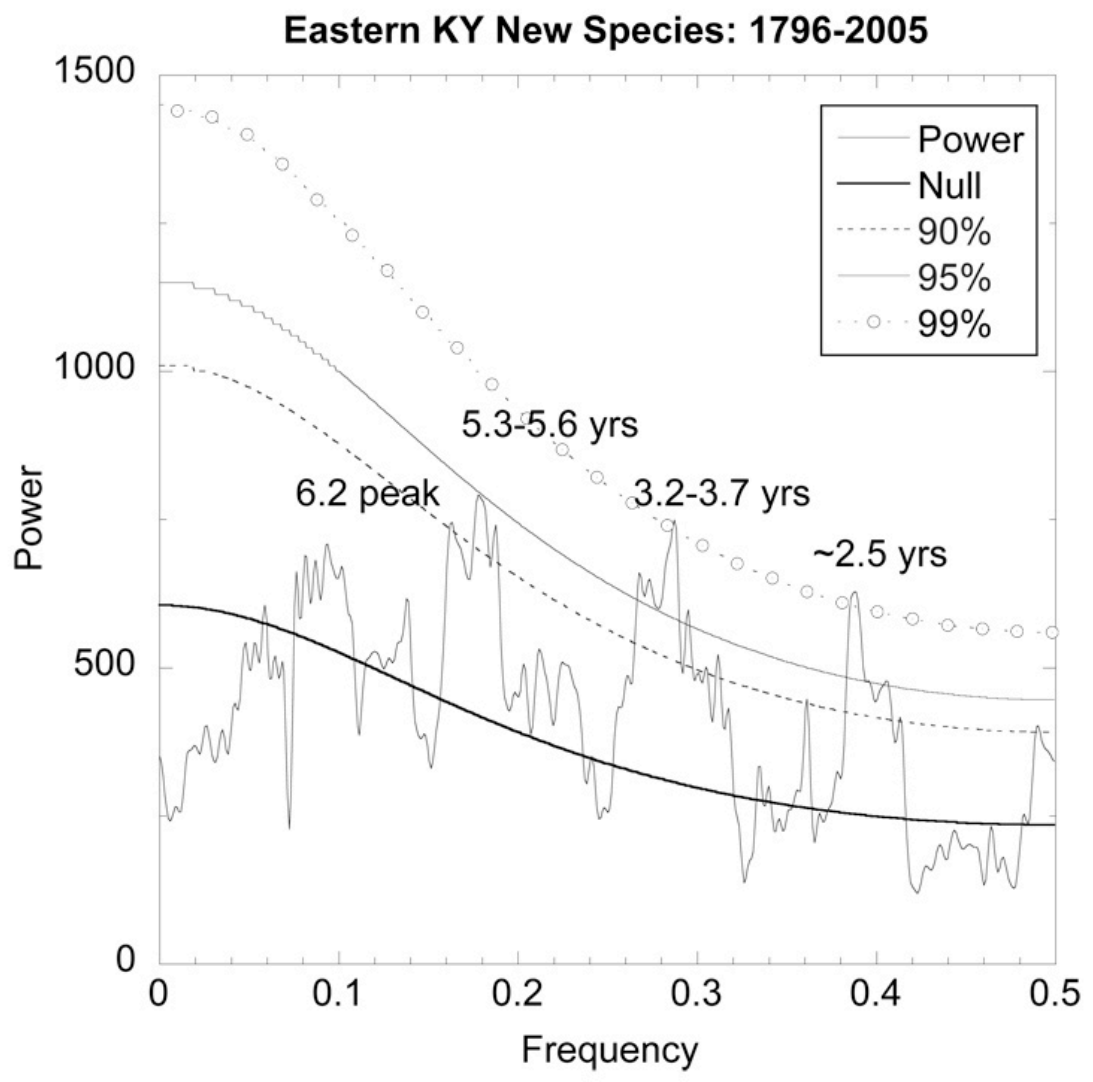

Figure S2 - Spectral analysis for the combined records of potentially new dendroclimatic data from eastern Kentucky. The lower, smooth and solid curve on each graph represents the null hypothesis. The dotted, smooth curve represents the $90 \%$ confidence limit (CL). The thinner smooth curve above the $90 \% \mathrm{CL}$ is the $95 \% \mathrm{CL}$. The dashed, line with circles represents the $99 \%$ CL. Numbers on each graph represent significant periodicities for each record. Graphs are arranged so spectral frequencies can be compared by species. Spectral analysis was conducted on ring index from 1796-2005 except for Lilley Cornett Woods (1796-1982) and Mammoth Cave National Park (1796-1985). 


\section{Spectral Frequency of Mixed, Signal-free and ARSTAN PC Series}

Care was taken when using signal free standardization on some of the records in our network. Records that included what seems to be a stand-level disturbance event (e.g., Blanton Forest, N. Pederson, unpublished data) retained this level of disturbance in the final signal-free chronology. These records were replaced with the original ARSTAN chronologies. A PCA was run of the new network that included signal free and ARSTAN chronologies. The PC scores of this analysis did retain more spectral power at decadal-scale frequencies, but none were significant (Figure S3). 


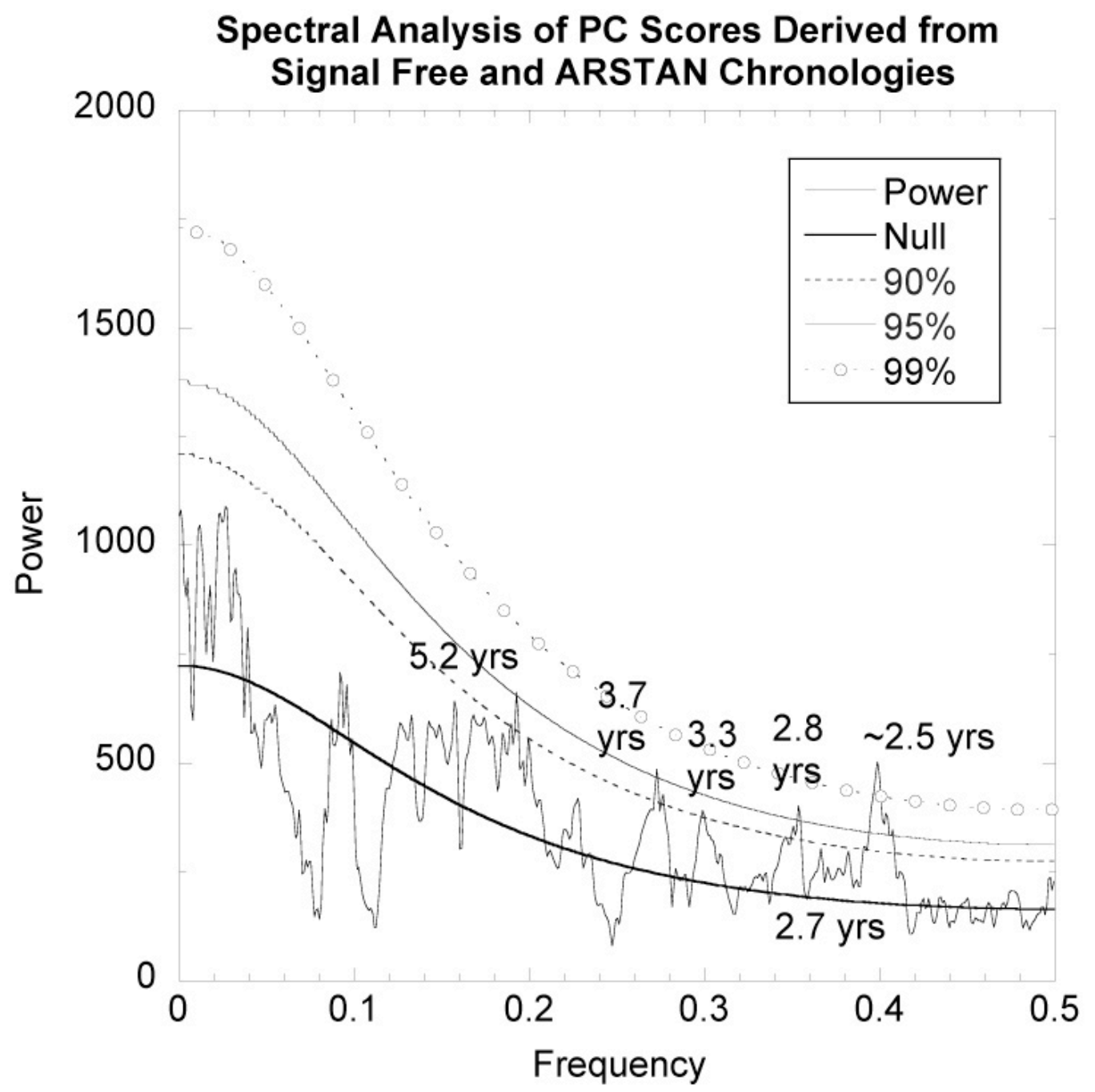

Figure S3 - Spectral analysis of PC scores derived from a mix of signal-free and ARSTAN chronologies from eastern Kentucky. The lower, smooth and solid curve on each graph represents the null hypothesis. The dotted, smooth curve represents the $90 \%$ confidence limit (CL). The thinner smooth curve above the $90 \% \mathrm{CL}$ is the $95 \% \mathrm{CL}$. The dashed, line with circles represent the $99 \%$ CL. Numbers on each graph represent significant periodicities for each record. Graphs are arranged so spectral frequencies can be compared by species. Spectral analysis was conducted on ring index from 1633-2005. 


\section{References}

Cook, E.R., Krusic, P.J., and Jones, P.D. 2003. Dendroclimatic signals in long tree-ring chronologies from the Himalayas of Nepal. Int. J. Clim. 23(7): 707-732.

Cooper, A.M. 2011. Age, forest structure, and disturbance history of five potential old-growth forests in eastern Kentucky's Cumberland Plateau. M.Sc. Thesis, Department of Biological Sciences, Eastern Kentucky University, Richmond, KY.

Meko, D. 1997. Dendroclimatic reconstruction with time varying predictor subsets of tree indices. J. Clim. 10(4): 687-696.

Pederson, N. 2010. External characteristics of old trees in the Eastern Deciduous Forest. Natural Areas J. 30(4): 396-407.

Schweitzer, C.J., Clark, S., Gaines, G., Finke, P., Gottschalk, K., and Loftis, D. 2008. Integrating land and resource management plans and applied large-scale research on two national forests. In Integrated restoration of forested ecosystems to achieve multiresource benefits: proceedings of the 2007 National Silviculture Workshop. R. L. Deal (ed.). U.S. Dept of Ag., Forest Service Gen. Tech. Rep. PNW-733. pp. 127-134.

Tackett, K. 2012. Forest dynamics of two old hemlock-mixed mesophytic forests. M.Sc. Thesis, Department of Biological Sciences, Eastern Kentucky University, Richmond, KY. 